\title{
Terrorism and Extremism: Approaches to the Study
}

\author{
Tankenova Laura Kumarovna ${ }^{1}$ \\ ${ }^{1}$ KAZAKH-AMERICAN FREE UNIVERSITY (KAFU), Doctoral Kazakh American Free Universiry, \\ Ust-Kamenogorsk, Kazakhstan
}

Correspondence: Tankenova Laura Kumarovna, KAZAKH-AMERICAN FREE UNIVERSITY (KAFU), Doctoral Kazakh American Free Universiry, Bozhova str., 68, Ust-Kamenogorsk, Kazakhstan. E-mail: Lauka_k@mail.ru

\author{
Received: October 31, 2014 Accepted: November 27, 2014 Online Published: February 25, 2015 \\ doi:10.5539/ass.v11n6p150 URL: http://dx.doi.org/10.5539/ass.v11n6p150
}

\begin{abstract}
This article discusses the scientific research of terrorism and extremism carried out by scientists from Kazakhstan, Russia and some other countries. A variety of approaches and methods used by experts are studied. The theoretical and practical importance of scientific papers dealing with terrorism and extremism is shown. The authors pay particular attention to the conceptual study of terrorism and extremism. It is noted that the concepts of terrorism and extremism are sometimes confused and equaled not only in the general social, but also in scientific ideas. Research conducted by the authors revealed the absence of clear wording of terrorism and extremism, the mixing of these concepts in scientific works and in the criminal law in different countries. In this regard, the authors justify the need for a clear separation of the concepts of terrorism and extremism in the criminal law to uniquely qualify these crimes.
\end{abstract}

Keywords: research, terrorism, extremism, approach, methodology, conceptual studies, practical value

\section{Introduction}

One of the main real threats to the national security of Kazakhstan, Russia and any other state, as well as the whole international security, is terrorism and extremism, which globally demand for not only the attention of the international community, coordinated actions of the security forces, but also for qualified research, the results of which can be used to enhance the effectiveness of the fight against this phenomenon.

Investigation of the nature of phenomena such as terrorism and extremism is necessary, in particular, for the development of methods for dealing with them, fundamentally solving the problem.

Comprehensive research, summary and generalization of its findings may be used to create a general theory of terrorism and extremism, on the basis of which the major bases for this phenomenon can be identified. It will become clear what is necessary to destroy and in what order to undermine and destroy these bases.

The purpose of this research is the study of the content of scientific knowledge about the phenomena of terrorism and extremism. The aim was to explore how the representatives of the various sciences from different countries understand these phenomena, to which ideas and concepts they appeal by attempting to explain the essence and nature of terrorism and extremism. In addition, it was necessary to find some common line in the understanding of these phenomena, produced by researchers from Kazakhstan, Russia and some other countries, as well as determine what benefit the research can bring to the process of confrontation by the world community to the threats posed by terrorists and extremists.

The need to address various scientific concepts in our study is due to a number of reasons. We see scientific concepts as a special form of collective knowledge that expresses attitude to social reality that is adopted by special subjects-representatives of the scientific community. Scientific ideas may have different internal bases and may be determined by either the arisen situation, or on the basis of knowledge accumulated by the representatives of the various sciences and selected social and cultural values.

Interest in this study is related to the changes that occur in the social reality in the framework of social and economic and social and political reforms in Kazakhstan. Another reason that determines the relevance of this research is the applied aspect of the problem associated with the increased role of the factors of legal and moral responsibility in society. 


\section{Methodology of the Study}

Goal to get not only theoretical but also applied results necessitates the use of divergent methodological techniques and methods to determine the required concepts, in particular, terminology identification of terrorism, extremism and the related effects.

It should be noted that the process of the study of these phenomena is complicated by the fact that the problems of terrorism and extremism, their different forms and manifestations are located at the intersection of different fields of human knowledge: philosophical, legal, political, sociological, psychological, etc., and without a deep theoretical and philosophical and political and legal analysis it is impossible to come to any firm conclusions.

Thus, the use of certain methodological techniques from various fields of knowledge to the researchers of the problems of terrorism and extremism should not be an end in itself, but its own original system of knowledge, means to disclose the phenomenon, i.e. what this phenomenon is by itself, unlike all other effects.

After examining a large number of works devoted to terrorism and extremism, it can be said with some confidence that the research of the phenomena of terrorism and extremism as a crime with practical value is conducted mainly by the representatives of the three sciences: criminology, forensic science and criminal law. Accordingly, the methodology of this research consists of a set of techniques peculiar to the specified sciences. For criminology, it is primarily sociological research methods: mass surveys, analysis of documents directly or indirectly containing information of interest to the criminologist researcher; method of expert evaluations; observation. Psychological methods of studying personality characteristics and analysis of interpersonal relations and relations in the so-called small groups (e.g. student groups) are also used. Statistical methods based on the scientific study of various forms of statistics play an important role.

Sociological methods are also used in compiling criminological characteristics of terrorist and extremist crimes, in the study of tactical decision-making process of the investigator in the investigation of these crimes, etc.;

The basic methods in the criminal law study of the phenomena of terrorism and extremism are: formal dogmatic (legal), historical and comparative, sociological, systematic, comparative jurisprudence (comparative), criminal statistics and others.

\section{Findings of the Study}

As a rule, the scientific study of terrorism and extremism, as well as many other categories related to the social sciences, begins with their lexical interpretation, which is widespread in science and relies on the commitment to "a kind of extreme views" and "the use of violence against the population in order to impact the activities of the authorities", but also the study of factor complex phenomena under consideration in their universal interconnection. At that, practical importance of this factor approach is that it cannot ignore the problem of removability of the causes and conditions of criminal behavior, which can be characterized as a terrorist or extremist activity. However, looking ahead, it should be noted that in reality, the complete elimination of the negative factors of this kind at the present stage of development of civilization is impossible because it would involve a fundamental change in the social and political system in such a way that it would inevitably limit basic social values and create the threat of even more dangerous social phenomena. So, in our opinion, it is possible to join the opinion of some researchers that the phenomenon of extremism and terrorism is the flip side of democracy, and terror as a phenomenon is only possible in a democratic state. For example, D.M. Feldman argues such a position with the fact that only the totalitarian state perfectly confronts the terror. This, according to him, is due to the fact that the main terrorist in the dictatorship state is the official government itself, which controls all media and which perfectly copes with the competitors. In a democratic state, D.M. Feldman says, participation in the institutions of civil society will inevitably put pressure on the government. Consequently, extremists and terrorists solve propaganda problem: they convince people that everything is the authorities' fault, as they lead a wrong policy (Feldman, 2004).

Conceptualization of terrorism and extremism is of great practical importance. Without an analysis of the causes and nature, features and connection with the complex of the changes occurring in the world, the fight against terrorism and extremism is also impossible, which will be much more productive if the public authorities take into account the available scientific conceptual development of terrorism and extremism in their preventive work to eliminate its causes.

Conceptual development in the existing literature on this subject uses a variety of research approaches: psychological and sociological, political science and civilization (Maltseva, 2006)

The Freudian and neo-Freudianism teachings about natural attraction to aggression, the origins of the biosocial necrophilia as a life orientation are an important theoretical source in identifying the social and philosophical 
nature of terrorism in its modern conceptual idea on the basis of the psychological approach. Fixing our agreement with S. Freud and E. Fromm on the influence of biological (genetic or psych pathogenic) factors on the propensity for violence, we note that the potential of these factors becomes a reality only under certain social conditions.

German scientist E. Hoffer in his "The True Believer" work had a profound analysis of mass psychology, those of its features that form the type of extremist who is a deeply convinced man with destructive tendencies. Among these traits are people's desire for change and impermanence, the willingness to move from words to action to become "useful" with the participation in their mass events. Misery and poverty, excessive expectations, sharp change of identity, excessive selfishness, desire for leadership, etc. also play a major role, according to this researcher (Hoffer, 1989).

The US researchers N. Zinberg and G. Fellman noted: "Human nature in itself, regardless of any external factors, has an element of destructiveness, the nature and dynamics of this destructiveness can only be understood on the basis of the study of this nature, and only in this way an effective method to put an end to all manifestations of violence in society can be found" (Zinberg \& Fellman, 1970).

Somewhat different analysis of terrorism is presented in the social and psychological theory of the US ethnopolitologist T. Gurr. The concept of deprivation explains aggression as a result of contradictions between the expectations, wishes and needs of a social group. According to this concept, any terrorist protest movement is based on resentment, revenge for the way of provision of specific national, legal, economic and other rights to a particular group of people (Gurr, 1974).

German lawyer and political scientist Carl Schmitt believes that the specificity of political activity (as well as in determining the features of the aesthetic, ethical and economic) can be determined by identifying the main problem, in this case-solved by the politics. The aesthetic solves the problem of the relationship between beauty and ugliness, the ethical-that of the relationship between good and evil, the economic-that of suitable and unsuitable, profitable and unprofitable. "The specific political distinction to which we can reduce political actions and motives is the distinction between friend and enemy" (Schmitt, 1992).

Definition of the political also allows us to understand the essence of depoliticization, as if the distinction between friend and enemy is lost, the political life also disappears in general (Schmitt, 1992).

Revenge and self-assertion, the willingness to sacrifice the life is extremely important for archaic politicization. These, of course, are psychological factors, but not only in terms of individual psychology, but also the collective archetype of the archaic politics. It is recovered from the deep layers of the culture of traditional societies destructed by money, material and technological temptations. However, despite this archaic lining and metaphysical goals of radical Islam (for example, the creation of an Islamic caliphate), the extremists pursue practical goals: by provoking the outrage of minds, to achieve the change of pro-Western regimes in Pakistan, Saudi Arabia and Egypt. The response rhetoric of Bush also appeals to the archaic principles of the US political consciousness. In practice, the goals of the American president were to not to allow to overthrow these regimes, destroying the camp of anti-American terrorists in Afghanistan and to take control of the oil reserves of the Persian Gulf (Maltseva, 2006).

One of the reasons for the appearance of illegitimate, archaic political players in the international arena is the growth of elements of anarchy in the 1990s (the weakness of the central government and international institutions, the lack of common collective ideas and values) in the international system, particularly in post-communist countries (Wendt, 1992).

American political scientist Alexander Wendt has shown that three categories or roles are fundamental for anarchy: of the enemy, rival and friend-each of which corresponds to the Hobbesian, Lockean and Kantian idea of society. Although in reality these forms of social relations can co-exist, Wendt saw them as the ideal model of international relations (Wendt, 1999). It is clear that the main figure of the Hobbesian reality, i.e. the war of all against all, the continuous destruction of the status quo, is the enemy. Lockean structure, in which civil society interacts with the state, corresponds to the Westphalian system that does not exclude the war between rival states. The "other" in the Kantian model of perpetual peace becomes a friend. Archaic politicization threatens the emergence of Hobbesian war of all against all. While the world suffers smaller losses from terror than from war, with developed technological equipment (e.g. nuclear weapons) they might be comparable (Maltseva, 2006).

So, in the framework of political science approach with respect to the concept of terrorism, there are two points of view. In one case, terrorism appears as the last fight of traditionalism, because the whole life of the so-called traditional societies does not know the politics in the modern sense of the word, and in the other-as a way of 
fighting the most backward states with strong, technologically advanced nations with whom they may come into direct fight.

Investigation of the essence and nature of extremism in Kazakhstan have been started only recently, since the late 90 s of the last century. Accordingly, the objective scarcity of studies on this issue should be noted.

It is noted that the vast majority of studies of Kazakh scientists, however, tell about primarily, if not exclusively, religious extremism. At the same time, many of the studies in the world are questioning the direct link between religion and terrorism. It seems that there is no direct link between them. Religion is likely to be used as a symbolic resource for legitimization and justification of terrorist activities. Anti-terrorism legislation should be directed not against the conviction, but against acts that violate the Constitution and laws of the country, in spite of their motives and impulses (Dronzina, 2011).

In the absence of conceptual studies, it nevertheless can be said that the approaches to the study of nature of extremism by a number of Kazakh scientists presented in some scientific works may be of some interest. A.A. Zharylganov, based on historical and comparative legal analysis, identifies the following signs of terrorism as a social and political phenomenon:

- special methods of terrorist activities, including the use of violence; destruction (damage) of property or threat of adverse effects; creating conditions that are dangerous to human life, health, safety of their property;

- deliberate creation of a climate of fear;

- publicity, propaganda nature of terrorist acts;

- direct harm is inflicted to the interests of some subjects, and the purpose of the relevant socially dangerous acts is forcing to a specific behavior in the interests of the terrorists by the others;

- increased public danger (Zharylganov, 2013).

The indicated author offers a typology of terrorism based on its division to the state, domestic and international.

Another researcher, E. V. Tukumov, rightly argues that in each case of extremism in the specific state or society, not only shall their own, specific factors take effect, but there are some common causes of this phenomenon in the modern world. Summarizing the above main reasons that determine the appearance and existence of extremism, the indicated author comes to the conclusion that deserves attention: that extremism is most active during a state of permanent political instability, weak institutions of the state, as well as during the economic crisis (Tukumov, 2004).

G. B. Zhusupova believes that the essence of extremism is the ideas and beliefs, motives and goals in their dialectical inseparability. Ideological shells are used to mask the main goal-a new division of the world and the redistribution of the real power between the subjects of world politics (Zhusupova, 2012).

In the opinion of this author, extremism acts as conscious activity and is aimed at bringing a result by extreme means different from established norms and rules. In order to achieve the extremist objectives, any methods can be used, both violent and devoid of violent content. Manipulation (as a system of action) is carried out by various methods, including psychological methods, trading and financial sanctions or political means.

To date, the legal science has no single conceptual approach to the definition of extremism. In itself, the phenomenon of extremism can be characterized as the spread of radical ideas, dogmas, doctrines in order to eliminate the possibility of the free flow and exchange of ideas; to establish its own ideology as a national one. V. V. Ustinov in his writings on terrorism has described extremism as "aggressive behavior (attitude) of the person, the most significant external manifestations of which are intolerance to the opinion of the opponent focused on common social norms; propensity to extreme (power) solutions to the problem; failure of consensus... rights of the person and their inherent value" (Ustinov, 2002).

Absence of the unified approach to the definition of "extremism" in Russian jurisprudence can be explained by 83 subjects of the Federation existing on the territory of modern Russia, each of which has its own traditions and specific features of the regional structure and historical mentality and, therefore, it is fair to remark that each subject and the region is characterized by their own extremism with its specific manifestations. A particular challenge is the fact that it is impossible to determine "where the free flow of ideas, doctrines, currents ends and extremism as an attack on this freedom begins" (Golubykh \& Legotin, 2013).

In the theory of criminal law, the view prevails that terrorism is an extreme and most dangerous form of extremism, that these concepts are related as species and genera (Ustinov, 2002; Fridinskiy, 2004; Dolgova, 2008), and some scientists even single out the extremist terrorism (Vasilchenko \& Shvyrkin, 2008). This is how 
the relationship between extremism and terrorism is understood in international law, in which terrorism is described as one of the manifestations of extremism. For example, in the Preamble to the Declaration on Measures to Eliminate International Terrorism, adopted on 9 December 1994 by the Resolution 49/60 at the 84th plenary meeting of the UN General Assembly (current international law, 1997), the deep concern is expressed that in many parts of the world the acts of terrorism are increasingly committed, which are based on intolerance or extremism. However, the principles of scientific research do not allow mixing concepts. There is no doubt that there is some connection between the above studied phenomena, but the differences are also significant. The literature has repeatedly expressed wishes to clearly demarcate terrorism and extremism (Khlebushkin, 2007; Arutyunyan, 2008; Sysoev, 2008.)

Separation of the two above studied phenomena is of undoubted interest, but as part of our study, we confine ourselves to a brief overview of opinions on this matter and justify their own point of view.

Russian criminal law treats these two groups as separate crimes: extremist crimes are attributed to attacks on the foundations of the constitutional order and security of the state, while terrorist crimes-to attacks on public safety. Thus, the Russian criminal law does not reflect the genetic relationship between extremism and terrorism.

The scientific literature suggests that "terrorism is the most dangerous form of extremism" (Kochoi, 2005), but the provisions of the Criminal Code of Russia do not allow us to conclude such a relationship between terrorism and extremism. Firstly, the articles 205, 205.1, 205.2 of the Criminal Code of Russia, providing the liability for the criminal acts of a terrorist nature, do not list political, ideological, racial, ethnic or religious hatred or enmity or hatred or enmity towards a particular social group as a possible motive.

Moreover, terrorism requires a very specific purpose of committing a criminal act-the impact on decision-making of the authorities or international organizations (part 1 of article 205 of the Criminal Code of Russia). Secondly, the list of criminal attacks, facilitating the commission or funding of which is a crime, does not include extremist crimes. Thirdly, the article 3 of the Federal Law dated March 6, 2006 No. 35-FZ "On Combating Terrorism" (Code of Laws of Russia, 2006, No. 11, article 1146) does not have any indication of extremism or hate motive on racial, national, political, ideological or social basis in the description of the concept of "terrorism", "terrorist activity" and "terrorist act" either.

At the same time, the laws of foreign countries often separate offenses related to terrorism and extremism, and the factor of extremism is not properly reflected. Legislations of most countries do not share the concept of "terrorism" and "extremism", they are limited to only listing the acts which, if committed by terrorist purposes, are recognized as terrorist acts, or use the term "terrorism". In the case of evidence of committing criminal acts for terrorist purposes, the criminal responsibility grows (Kuchumova, 2012).

Thus, a foreign legislator often lacks such an important element as the ideology of violence or extremism in legal regulation. This situation is, however, does not satisfy the leadership of individual countries. The former French President Nicolas Sarkozy, in particular, declared the adoption of penal measures against the promotion of "doctrines based on the ideology of extremism" via the Internet, on March 22, 2012 (Kuchumova, 2012). The head of state demanded criminal penalties for visiting the "terrorist sites" on the Internet. It is also noted that it was intended to introduce regulations to the Criminal Code that would criminalize "apology for terrorism" or "incitement to hatred and violence."

It should be noted that the analysis of articles 233-3, 233-4 suggests that the definition of terrorism and extremism in individual standards are used interchangeably in the Criminal Code of Russia, which seems wrong.

\section{Conclusion}

Thus, the results of a study of scientific ideas about the content of the phenomena of terrorism and extremism allow us to draw some conclusions. The researchers in scientific studies that contain research of terrorism and extremism often use the methodology of the sociological approach that seems to be justified, if we accept the assertion that the crime is a phenomenon generated by the society as true. The value of the sociological approach is seen also in the fact that it extends the subject and scope of the study, allows to determine the social contradictions in society, thereby identifying the underlying causes of terrorism and extremism. At the same time, a number of causal factors, as mentioned above, may be peculiar to a particular state, and even to a region within large countries such as Russia and Kazakhstan, which increases the importance of criminological research of the features of national and religious specificity of terrorism and extremism.

The studies also show that not only in the public consciousness, but also among experts, a tendency prevails to equate or confuse the concepts of terrorism and extremism. Laws of many countries often lack evidence-based definition of terrorism and extremism, one of the phenomena in the law is expressed as the sign of another, 
which violates the principles of the law, leads to errors in the classification of crimes, and generally has a negative impact on the regulation to combat these phenomena. In our opinion, in spite of external similarity and a certain relationship, terrorism and extremism are although the phenomenon of the same order, but not a special case or the extreme case one of another. These phenomena can exist both separately from each other and interconnected in practice. Nevertheless, it seems that at present, when the vast majority of the most resonant terrorist acts are committed by the members of extremist organizations of various kinds, conducting complex fundamental research of each of the two phenomena without the other is meaningless. In our opinion, the current research of the phenomena of terrorism and extremism should be aimed at developing some common line against terrorism and extremism, which should result in formation of the basis of the general theory, the provisions of which, in turn, should be considered in the development of modern legislation able to deal with threats these phenomena carry.

At the same time, in our opinion, it is necessary to conduct further research into the study of social ideas of terrorism and extremism of the representatives of different age and social groups, as well as studies of individual factors of varying degrees of importance, influencing the formation of extremist and terrorist activity.

\section{References}

Arutyunyan, R. F. (2008). Counter organized terrorism in the Caucasus region of the CIS. Moscow.

Dolgova, A. I. (2008). Extremism and terrorism, terrorist and other extremist crimes: Concept, analysis, dynamics. Extremism and other criminal phenomena. Moscow: Russian Criminological Association.

Dronzina, T. (n. d.). Multifaceted sources of terrorism. Retrieved October 20, 2014, from http://counter-terror. $\mathrm{kz} / \mathrm{ru} / \mathrm{article} / \mathrm{view}$ ?id=211

Federal Law "On Combating Terrorism" of 06.03.2006 \#35-FZ.

Feldman, D. M. (2004). The downside of democracy. Version, 20(293).

Fridinskiy, S. N. (2004). The fight against extremism: Criminal and legal and criminological aspects. Moscow.

Golubykh, N. V., \& Legotin, M. P. (2013). On the essence of the concept of extremism. Lawyer.

Gurr, T. (1974). Why Men Rebel. Princeton: Princeton University Press.

Hoffer, E. (1989). The True Believer: Thought on the Nature of Mass Movements. New York: Harper Collins Publishers.

Khlebushkin, A. G. (2007). Criminal extremism: Concept, types, criminalization and penalization. Thesis of Candidate of Legal Sciences, Saratov Institute of Law, Saratov.

Kochoi, S. M. (2005). Extremism: Problems of counteraction. Modern variety of Russian and world crime: Status, trends, opportunities and prospects to counter (p. 288). Saratov: Saratov Center for the Study of Organized Crime and Corruption: Satellite.

Maltseva, V. Yu. (2006). Conceptualization of the term "terrorism". Russian Investigator, 12.

Preamble to the Declaration on Measures to Eliminate International Terrorism, adopted on 9 December 1994 by the Resolution 49/60 at the 84th plenary meeting of the UN General Assembly. Current international law (Vol. 3). (1997). Moscow: Moscow Independent Institute of International Law.

Schmitt, K. (n. d.). Concept of the Political. Questions of Sociology, 1(1), 40.

Sysoev, A. M. (2008). On clarification of the categories of extremist crimes. Russian Legal Magazine, 4.

Tukumov, E. V. (2004). Religious and political extremism as a threat to regional and national security in Central Asia. Thesis of Candidate of Political Sciences, Kazakhstan Institute for Strategic Studies under the President of the Republic of Kazakhstan, Almaty.

Ustinov, V. (2002). Extremism and terrorism: The problem of differentiation and classification. Russian Justice, 5.

Ustinov, V. V. (2002). Terrorism is accused (p. 16). Moscow.

Vasilchenko, A. A., \& Shvyrkin, A. A. (2008). Differentiation of terrorist and extremist crimes. Extremism and other criminal phenomena. Moscow: Russian Criminological Association.

Wendt, A. (1992). Anarchy is What States Make of It: The Social Construction of Power Politics. Intern. Organization, 46, 335-370. http://dx.doi.org/10.1017/S0020818300027764

Wendt, A. (1999). Social Theory of International Politics (pp. 246-312). Cambridge: Cambridge University Press. 
http://dx.doi.org/10.1017/CBO9780511612183

Zharylganov, A. A. (n. d.). Terrorism as a social and legal phenomenon. Retrieved October 20, 2014, from http://mvd.gov.kz/portal/page/portal/mvd/mvd_page/mvd_extremzim/mvd_Extremizm_publikacii/Teppopи $3 \mathrm{M}$

Zhusupova, G. B. (2012). Theoretical and applied problems of combating extremism in the Republic of Kazakhstan: Criminological aspects. Thesis of Candidate of Legal Sciences, Chelyabinsk State University, Chelyabinsk.

Zinberg, N., \& Fellman, G. (1970). Violence: Biological Need and Social Control (p. 223). Baltimore.

\section{Copyrights}

Copyright for this article is retained by the author(s), with first publication rights granted to the journal.

This is an open-access article distributed under the terms and conditions of the Creative Commons Attribution license (http://creativecommons.org/licenses/by/3.0/). 